\title{
Financial Statement Fraud in the Turkish Financial Services Sector
}

\author{
Lale Aslan1
}

\begin{abstract}
Financial statement fraud is a huge obstacle to economic growth and it results in the loss of investors' trust in the financial system. In literature, financial statement fraud detected in real sector companies is investigated thoroughly, however, financial statement fraud in financial institutions is somewhat ignored. In this article, the researcher investigates the typologies and frequencies of financial statement fraud detected by the regulator. The financial services sector framework is made up of companies like banks, intermediary institutions and portfolio management companies and the Capital Markets Board of Turkey (CMB) is the regulator and auditor for the Turkish financial services sector. The author based her research on the audit findings of CMB between 2012 and 2020. According to research results, intermediary institutions are found to be the riskiest type of institution with the majority of fraud cases and the most frequently seen type of fraud is asset misappropriation of client assets. Moreover, CMB is likely not to pursue legal allegations if the company in question is awarded a sanction according to the correlation analysis result. This article has a unique approach that combines jurisprudence and fraud cases and draws attention to financial statement fraud in the financial services sector, which is a pioneer for the Turkish economy.
\end{abstract}

Keywords

Audit, Regulation, Banks, Brokerage Firms, Portfolio Management

\section{Introduction}

Fraud can be defined as undercover efforts in publicly or privately owned institutions that are against legal regulations and aim to benefit the performer illegally. Fraud can take many forms from public scams that aim to deceive unsuspecting citizens to the application of complex techniques to financial data. Without any regard to the type of fraud, the consequence concerning the economy is similar to a dark hole in the universe. According to a PwC survey (PwC, 2018), there was an increase in fraud cases in companies from 2016 to 2018 and the majority of the fraud cases were caused by employees. Furthermore, top management is the fraudster in many cases.

The researcher will focus on the financial services sector in Turkey in this study. Financial services institutions are defined as banks, intermediary institutions and portfolio management

\footnotetext{
1 Corresponding Author: Lale Aslan (Asst. Prof. Dr.), İstanbul Yeni Yüzyıl University, Faculty of Economics and Administrative Sciences, Department of Business Administration, Istanbul, Turkey. E-mail: lale.aslan.phd@gmail.com ORCID: 0000-0001-6227-0557

To cite this article: Aslan, L. (2021). Linking Financial Statement Fraud in the Turkish Financial Services Sector. Istanbul Business Research, 50(2), 385-409. http://doi.org/10.26650/ibr.2021.50.844527
} 
companies for the context of this study. The Turkish financial services sector is a key example of the transformation which occurred in the said sector. Before 1999, the banking sector in Turkey lacked proper regulation as the main regulatory authority, Banking Regulation and Supervision Agency, was only founded in 1999 after a number of banks went bankrupt and a banking crisis. To overcome the tumultuous situation, a major structural reform was implemented, which greatly shaped today's economy. Therefore, Turkey is an important example of developing countries in this sense.

Moreover, in Turkey, capital market regulation underwent a complete makeover by the Capital Markets Board of Turkey (CMB) during 2012 - 2013 and the changes made in the regulation were heavily influenced by European regulations and the 2008 crisis. The research aims to investigate whether this expectation is true or not. Financial statement fraud is inspected by the CMB. Financial services institutions are required to prepare their financial statements according to Turkish Accounting Standards and Turkish Financial Reporting Standards announced by the Public Oversight Accounting and Auditing Standards Authority of Turkey. Furthermore, there are some sector-specific regulations announced by CMB. Auditing of these institutions is performed by $\mathrm{CMB}$ auditors, although all of these institutions are required to implement internal audit and control systems.

In this article, the frequencies, financial impact and fraud strategies of financial services institutions will be covered. Data from CMB audits between 2012 and 2020 will be examined. The standards and regulations of the financial services sector are greatly shaped by the 2008 crisis and this has possibly influenced fraudulent activities. Internal auditors of financial services institutions are responsible for informing the CMB of any problems concerning the financial situation of the institution. Moreover, intermediary institutions have to report their capital adequacy levels to the CMB periodically. Before the 2008 crisis, this reporting was required monthly. After the collapse of Lehman Brothers, CMB required capital adequacy reporting every week, which indicates increased measures to ensure strong and healthy financial institutions. The regulators expect that updated regulations after the 2008 crisis contribute to the prevention of financial statement fraud.

This study aims to attract attention to financial statement fraud in the financial services sector, which is a rather neglected topic in literature. Financial institutions are keystones of a healthy and well-functioning economic system. Any disruptions concerning these institutions will undermine the efforts of governments and central banks towards stabilizing the economy as the real sector depends on the finance sector for resources. It is possible to see many papers in the literature about financial scandals in conglomerates like Enron, WorldCom and Parmalat. There is no denying the damaging effect of these scandals on capital markets and the overall economy; however, financial statement fraud seen in the finance sector can cause many severe effects and possibly a nationwide crisis. Therefore, this article is dedicated to analysing the audit findings related to the financial services sector. 
Turkish literature concerning financial services fraud is limited to the perspective of employee fraud or bank clients' financial statement fraud. Even though there have been many failed banks in Turkey, not a single article covering these banks has been published. Since the framework of this article is to investigate the cases of fraud in the finance sector, this article holds a unique place in Turkish literature.

The outline of the paper features the theoretical background for financial statement fraud, the importance of the financial services sector, the relation of the economic environment to financial statement fraud, results of the financial statement fraud-related analysis in Turkey and a conclusion.

\section{Background}

Fraud is one of the most dangerous threats to a business at the micro level and it is a threat to the overall economy at the macro level. A sound economy can only exist where business transactions are made truthfully, and the bond of trust is not broken by any economic actor. After all, a fully functioning economy depends on the mutual trust of the parties, without it there will be disruption. Investors would like to think that the financial statements of a company show the real situation in a truthful manner. That is one of the reasons why a potential investor places their life savings in the stock markets. If the company's financial statements do not reflect any real problems that the company encounters, then investors are tricked into thinking that such an investment is worthwhile and when fraud is revealed, stock markets crash and all the investor's savings are lost. Therefore, the trust and bond between the investor and the stock market is damaged. This is why scandals like Enron, WorldCom and many others are so laboriously investigated. The economy management is tasked with ensuring the healthy functioning of capital markets and such fraud scandals prevent it from being so.

When top management is involved in fraud, it concerns financial statement fraud because generally, top management aims to exploit the resources of the company to their benefit and to cover their steps, they need to apply window dressing in financial statements. This can be the worst-case scenario for companies because the people who should be responsible for directing and enriching the company, act in their interest which is explained by the agency theory. According to the agency theory, there is an inherent conflict of interest between shareholders and management and consequently, there is a cost of using an agent. The internal control cost factor is the most essential contributor to agency cost as all major actions have to be under scrutiny to avoid fraud. However, it is not always possible to prevent fraud, because top management and shareholders do not give prevention measures the importance they deserve (PwC, 2018).

Shareholders have used compensation plans as a prevention tool for internal fraud. However, over -the-top compensation plans have attracted negative attention from the public, 
and whether senior management deserves such payments became questionable after the 2008 economic crisis. According to Acero \& Alcalde (2020), the economic performance of a company is independent of the compensation of senior management. This finding suggests that committing fraud has nothing to do with the payments made to top management; instead, fraud is more related to the incentives given to people.

\section{Basics of Financial Statement Fraud}

Financial statement fraud may take many different forms, depending on the ownership of the firm. If the organization in question is publicly owned, top management may have different worries concerning the financial statements when compared to a privately owned company. Publicly held firms are under pressure from investors to keep the stock market price high. Top management is inclined to commit financial statement fraud to cover up financial problems and buy enough time to find solutions. Some of the make-up techniques used in this endeavour consist of wrongfully increasing assets and income or decreasing debts and expenditures so that profits are also increased (Association of Certified Fraud Examiners (ACFE), 2003). If the company in question is not a publicly held corporation, then there is no pressure to keep the stock price high. The main concern of private companies is to increase profits and to achieve this goal top management tries to reduce tax payments either by understating sales or by overstating expenses. Therefore, types of financial fraud can be divided into two major categories according to the incentive. ACFE groups financial statements fraud into two categories: Overstating and understating assets and income. Moreover, earnings management, income smoothing, creative accounting, aggressive accounting and big bath accounting are types of manipulations that can be used in accounting. The most popular manipulation technique concerns the recording of expenditures (Zengin, 2018).

Financial statements fraud is either committed in order to make the business look better than it is, which serves to impress shareholders and investors, or to cover up over the top expenses aimed to benefit the senior management rather than the business (ACFE, 2020). Prevention of fraud is important because there is a great cost associated with it. Since the 2008 global crisis, there has been a 56.5 per cent increase in the cost of losses. The total amount of fraud cost is equal to USD 5.127 trillion globally (Gee \& Button, 2019). Moreover, companies take measures for the detection of fraud; however, these measures do not necessarily contribute to the prevention of fraud. Therefore, the global cost of fraud keeps on rising. According to ACFE (2018), 10 per cent of all fraud is financial statements fraud and its median is equal to USD 800,000 . Even though financial fraud occurrence is relatively low, the significance and cost of financial statements fraud are quite high, therefore it is the most dangerous type of fraud for enterprises and it results in clearing out the capital of companies and a definite loss for shareholders. 
In today's complex work environment, detection of financial statement fraud should not be left to conventional methods which provide post-event data. Technological advances have to be applied in fraud detection endeavours if the institution in question wants to implement realistic measures for fraud prevention (Chimonaki, et al., 2019).

One false assumption about financial statement fraud is that it is only committed by the top management of organizations. In some cases, external parties commit financial fraud as well. Generally, financial services companies are victims of such fraud schemes which occur when a client takes a large loan and does not pay it back. Worthless loans become the source of disruption for the financial institution (Carmichael, 2020).

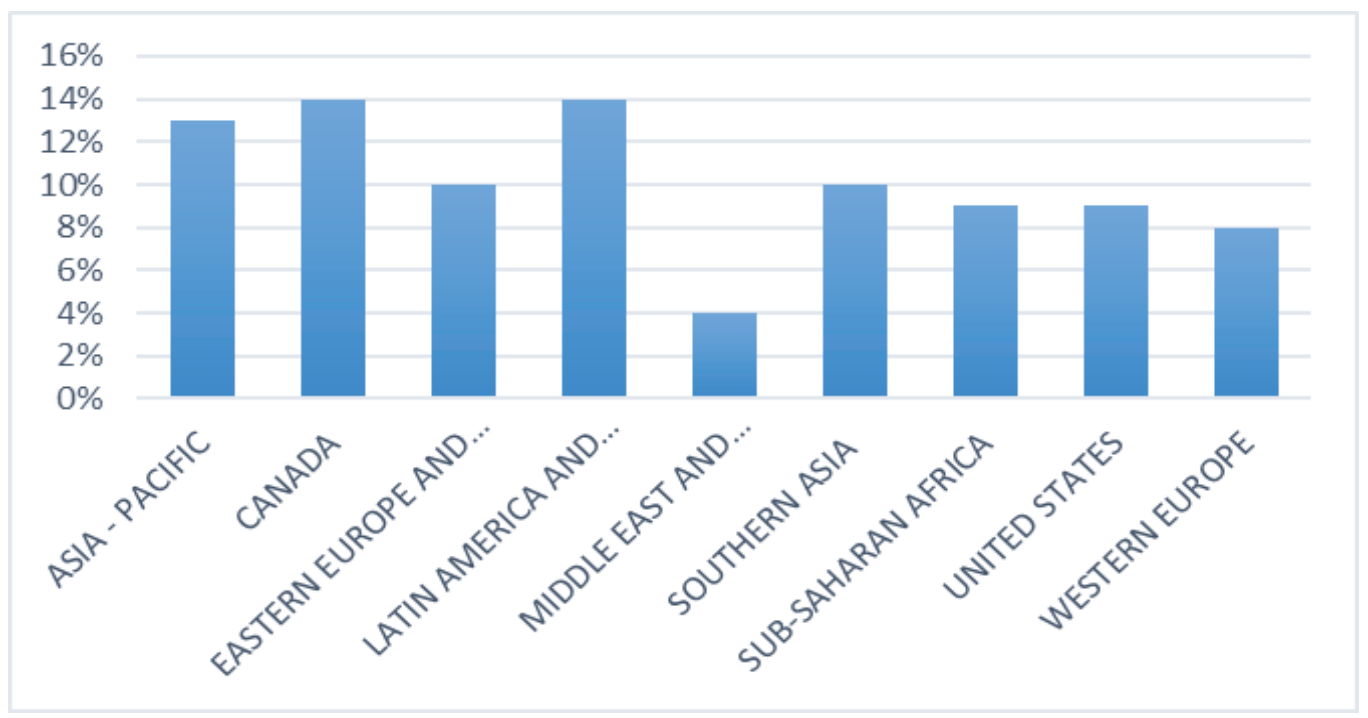

Figure 1. Financial Statement Fraud Percentage of Regions

Source: Adapted by the Author from ACFE (2018)

Figure 1 presented above shows that there are higher percentages of financial statement fraud in Asia - Pacific, Canada and Latin America regions. The rest of the world has financial statement fraud below 10\% while the regions stated above have over $10 \%$ financial statement fraud. The lowest percentage belongs to the Middle East and North Africa, although this region possibly lacks the qualified personnel to perform complex financial statement fraud techniques. Meanwhile, fraud losses are also highest in Asia - Pacific region with a median of USD 236,000 and the lowest amount of fraud loss is in Sub-Saharan Africa with USD 90,000 (presented in Figure 2 below). 


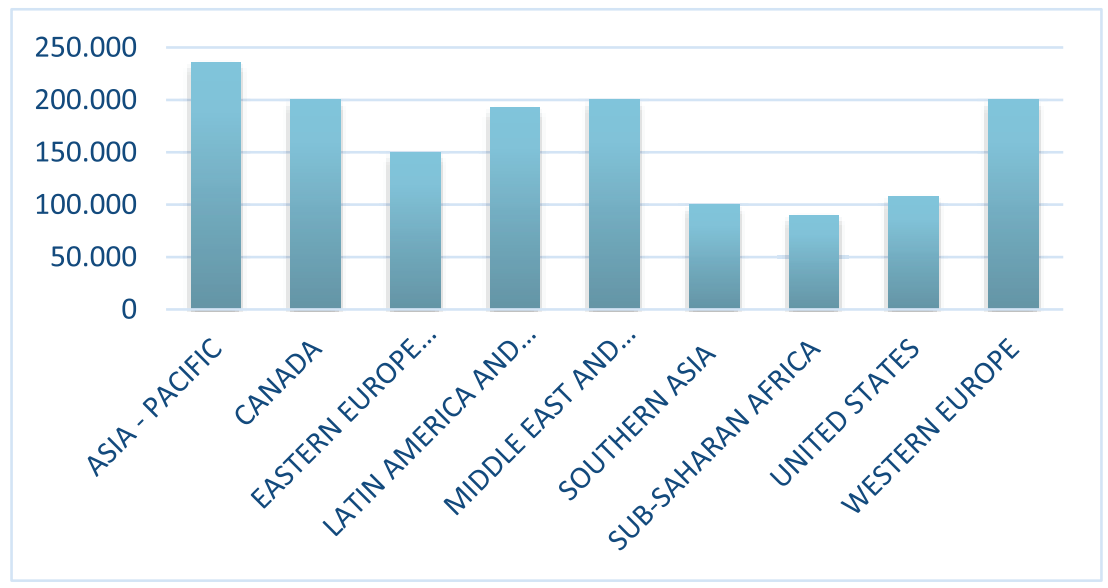

Figure 2. Fraud Losses in USD According to Regions

Source: Adapted by the Author from ACFE (2018)

In Turkey, data concerning fraud is not published, however, a small compilation of several fraud cases is given in Table 1 below. According to the table, the number of cases has stayed constant since 2014. However, any other information concerning these fraud cases is not made public. Therefore, it is not quite possible to present the big picture of fraud in Turkey.

Table 1

Number of Fraud Cases in Turkey

\begin{tabular}{cc}
\hline Year & Number of Cases \\
\hline 2020 & 13 \\
2018 & 13 \\
2016 & 15 \\
2014 & 13 \\
\hline Source: Compiled by the Author from ACFE Report to the Nations 2020.
\end{tabular}

\section{Financial Statement Fraud and Environment}

Financial innovation has brought many financial products that have made our lives easier, such as mobile banking and annuities. However, the 2008 crisis linked financial innovation with complex derivative instruments that are extremely risky and under regulated. Such complex instruments, for instance, asset-backed securities, were used to pump cash into the economy, resulting in a housing bubble. Without proper regulation and poor-quality loans, the bubble burst rapidly and the savings of people vanished as their assets lost value and they were left with credits higher than their assets' values. Therefore, the public has been suspicious of financial innovation products since the credit crisis.

The 2008 crisis is an indicator of how poor risk management is in the financial services sector. Still, many financial institutions have not integrated enterprise risk management and 
prefer to manage risk in silos, as if there is no interaction between risk types or risk-prone departments. Many financial services institutions still focus only on financial risks and ignore other risks they may face. Moreover, the 2008 credit crisis showed that financial institutions were not apt at managing financial risks either. The crisis accelerated the regulation updates needed to secure financial risk management in the finance sector, thus the Basel III accord was penned in 2010 as a response. However, regulators have not succeeded in implementing the accord as the date keeps getting postponed. The final proposed date is January 2022. The postponing of the application date of Basel III leaves banks vulnerable in managing financial risks. Furthermore, as financial institutions have not embraced enterprise risk management, they have not become fully guarded in facing fraud risks.

As the world moves into uncertain times, many different risks arise. According to the World Economic Forum (2019), there are many increased risks concerning financial institutions such as economic and political risks and cyber-attacks. In 2020 a new type of risk emerged. The COVID - 19 pandemic has affected the financial institutions, as the real sector was forced to shut down and many governments announced economic packages that postpone the payment of credits and forced down interest rates. Many financial institutions will start to feel the stress in their financial statements as profits start to decline. This situation will increase the possibility of fraud risk. Employees who have to fill a quota of sales will be unable to make sales with quarantine precautions and profits will plummet. Top management of financial institutions will be under strain from the downturn of the economy, which will act as a catalyst for financial statement fraud.

In the literature, there are very few articles that are concerned with financial statement fraud; whereas there are many theses written on the subject. There are only four articles written concerning financial statement fraud (Selimoğlu \& Altunel, 2019; Demir \& Arslan, 2018; Terzi \& Şen, 2015 and Terzi \& Şen, 2012). Selimoğlu \& Altunel (2019) present a literature review of master's and doctoral theses written between 2008 and 2018. Demir \& Arslan (2018) evaluate the tools used by internal auditors for fraud detection. Terzi \& Şen (2015) present a model of neural networks for the detection of fraud in forensic accounting. Terzi \& Şen (2012) develop a model of data mining for financial statement fraud detection. None of these articles are concerned with the financial services sector.

\section{The Outlook on Turkish Legislation and Economy}

Although: "Tax Procedure Law No. 213" (1961) is the main regulation that covers financial statement fraud in Turkey, it is written from the perspective of tax evasion. Article 359 states that any parties involved in fraudulent records in bookkeeping or financial tables shall serve between 18 months and 3 years in prison. It also defines the difference between forged documents and misleading documents. Forged documents are documents that are prepared 
without any relation to real events. Misleading documents are documents that are based on real events and situations; however, they have been altered to reflect an unrealistic event. Both types of documents are considered as evidence for financial statement fraud. Moreover, parties involved in the preparation and usage of forged documents shall serve two to five years in prison according to Article 359.

"Turkish Criminal Code No. 5237" (2004) Article 161 defines fraudulent bankruptcy. According to the article, in the case of fraudulent acts to reduce assets, if bankruptcy is concluded, related parties shall serve three to eight years in prison. Reducing assets has to take place by concealment or loss of value in assets, hiding or destroying related books, records or documents, preparing documents to create an illusion of a debt related to increasing the debts of the company in question and misleading representation of assets in the balance sheet. There aren't any other regulations in Turkey concerning financial statement fraud.

In the case of a financial statement fraud that results in bankruptcy for banks, there is a deposit insurance system established that will aid the depositors. This deposit insurance system is managed by the Savings Deposit Insurance Fund (SDIF) established in 1983. In 1994, SDIF was authorized to improve the financial situations of banks under its control. In 1999, the Banking Regulation and Supervision Agency (BRSA) was established and structural reformation in the banking sector took place due to a Standby Agreement signed by the International Monetary Fund (IMF) (Eser, 2007, 48). Moreover, SDIF's representation was also given to BRSA in 1999 . In 2003, SDIF achieved autonomy status. In 2005, SDIF was granted permission to regulate the sector and in 2016 SDIF received trusteeship power (SDIF, 2020).

The transfer process of a Bank to the SDIF begins after the detection of the following in a BRSA audit: the bank's liquidity does not cover its short term debt, the balance between income and expenses are distorted, capital adequacy is not met, asset quality disrupts financial structure, there are inadequate internal control and audit system and a weakening of the financial structure by inept management decisions. If these conditions are found in a BRSA audit, the bank is given a limited time to improve its finances; otherwise, the bank is transferred to SDIF ("Banking Law No. 5411", 2005, Article 67). The most important finding in a BRSA audit is the existence of a weakened financial situation borne from the owners or the managers of the bank using the assets for their gain. In this case, the BRSA management board is legally allowed to revoke the operating license of the bank, and transfer the management and control of the bank to the SDIF for sale or consolidation for covering the losses of the bank.

In 2000, the bankruptcy of Bayindirbank's foreign branch triggered a banking sector crisis in Turkey, which resulted in a financial crisis in 2001. After the bankruptcy of Bayindirbank, many banks were transferred to SDIF, the common ground in these transfers were the weak financials of these institutions. Not all banks were involved in fraud, however, in any case, 
the banking sector was quite fragile in the 2000s and couldn't cushion the shocks directed from outside. With such an experience in its past, the Turkish banking sector was structured to possess better quality assets as Basel I and II were adopted. As the banking sector crisis turned into a financial crisis, it is possible to assume that the health of the banking sector is quite vital to the overall economy. Therefore, any fraudulent activity in the finance sector should be prevented for a well-functioning economy.

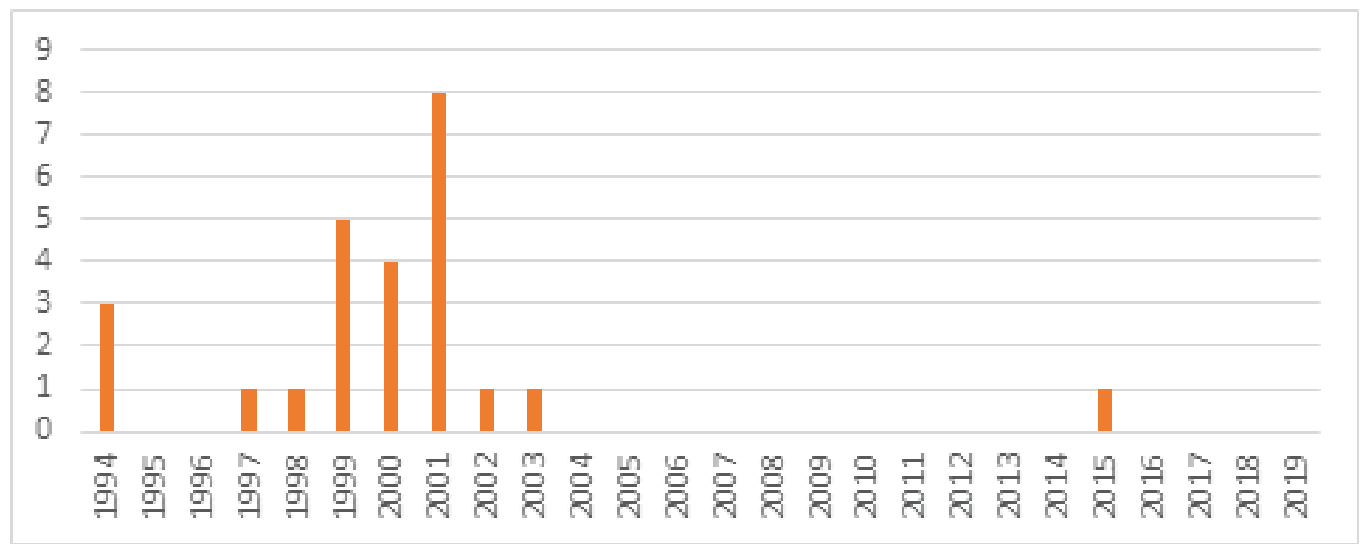

Figure 3. Frequency of Bank Transfers to SDIF

Source: Compiled by the Author from SDIF (2020)

Figure 3 above depicts the frequency of bank transfers to SDIF between 1994 and 2019. According to the figures, the period between 1999 and 2002 shows a density in bank transfers to SDIF as this is the period covered in the IMF Standby Agreement. Table 2 below gives the list of banks transferred to the SDIF between 1999 and 2002. This agreement is of key importance as it required the restructuring of the banking system.

Table 2

List of Banks Transferred to SDIF

\begin{tabular}{lcc}
\hline Status & Bank & Year It Was Transferred To SDIF \\
\hline & TYT Bank & 1994 \\
& Marmara Bank & 1994 \\
Banks whose operating license has been revoked & Impexbank & 1994 \\
& Cyprus Credit Bank & 2000 \\
& Imar Bank & 2003 \\
Banks Resolved by Direct Selling & Bank Asya & 2015 \\
& Bank Ekspres & 1998 \\
& Demirbank & 2000 \\
\hline
\end{tabular}




\begin{tabular}{lcc}
\hline Status & Bank & Year It Was Transferred To SDIF \\
\hline & Egebank & 1999 \\
Banks Sold After Merging & Yurtbank & 1999 \\
& Yasarbank & 1999 \\
& Bank Kapital & 2000 \\
Banks resolved by Transferring to Another Bank & Ulusal Bank & 2001 \\
& Sumerbank & 1999 \\
& Pamukbank & 2002 \\
Banks merged and resolved & Interbank & 1999 \\
& Esbank & 1999 \\
& Etibank & 2000 \\
Banks resolved by voluntary liquidation method & Iktisat Bank & 2001 \\
Existing Banks within the SDIF & Kentbank & 2001 \\
\hline
\end{tabular}

Source: Compiled by the Author from SDIF (2020

\section{Financial Statement Fraud in The Turkish Financial Services Sector}

In Turkey, the CMB performs regulation and auditing of the financial services sector. The CMB has critical functions in the financial markets including regulating the said capital markets, approving paperwork for initial public offerings, providing permit for performing capital market activities such as trading of securities, portfolio management and investment advisory, as well as, monitoring of capital market activities performed by financial institutions and publicly held corporations, and auditing and sanctioning of these institutions. Financial statement fraud is a highly sensitive subject in capital markets, and the CMB has the authority to audit financial services institutions for unveiling any kind of financial statement fraud that has taken place in financial institutions. The CMB is responsible for regulating and auditing investment institutions like banks and intermediary institutions, funds, investment trusts, portfolio management companies, real estate appraisal companies, licensing agencies and independent auditing firms. However, the extent of this article is limited to banks, intermediary institutions and portfolio management companies as these institutions make up the core of the financial services sector.

As of September 2019, the trading volume in the equity market equaled TRY 2,120 billion, of which TRY 1,967 billion belongs to brokerage firms and TRY 153 billion belongs to banks. In the fixed income market, brokerage firms' transactions equaled TRY 83 billion and banks performed transactions equal to TRY 354 billion. In the repo - reverse repo market trading volume of brokerage firms amount to TRY 1,587 billion and banks have a trading volume of TRY 6,336 billion. Brokerage firms are more active in futures markets than banks, with a trading volume of TRY 1,176 billion as opposed to TRY 62 billion. The options market 
is somewhat smaller than the futures market with TRY 10 billion trading volume of brokerage firms and TRY 3 billion trading volume of banks. The total amount of leveraged FX transactions equals TRY 2,767 billion (Turkish Capital Markets Association, 2020b).

\section{Research Problem}

The financial services sector is vital for economics and financial inclusion is the key to stopping growth in the grey economy and directing this growth towards the legal economy. The financial services sector includes commercial and participation banks, intermediary institutions and portfolio management companies. With the 2008 economic crisis, it became clear that the financial services sector is prone to great uncalculated risk. The financial risk of these institutions is so great that it affects their financial statements. Therefore, regulations concerning the financial situation of banks, intermediary institutions and portfolio management companies became a focal point for regulators in the aftermath of the crisis. Moreover, top managers often commit to window dressing techniques and actions which cause public opinion to turn even more negative. The finance sector is built on mutual trust, the trust in clients that they will pay their debts and the trust in the institutions that they will protect the savings of the customers. With such fraudulent schemes, this bond of mutual trust is broken. Therefore, companies have to pay more attention to their public image. The financial security of the financial services sector is of the utmost importance since the health of the overall economy is at stake.

Even though the financial services sector is the most heavily regulated, the majority of financial fraud is seen in financial services companies (Reurink, 2016). The median of loss due to fraud in the financial services sector equals USD 110,000 around the world. The most common fraud types seen in the banking and financial services sector are billing, cash larceny, cash on hand, check and payment tampering, corruption, expense reimbursements, financial statement fraud, noncash, payroll, register disbursements and skimming. The percentage of financial statement fraud in financial services equals $8 \%$ (world data). The financial services sector has compliance departments, certified employees and a code of conduct in place.

Moreover, the sector is audited by external auditors. However, these controls are simply not enough to prevent financial statement fraud (ACFE, 2018).

Since the financial services sector is so important to the health of the overall economy, the researcher will focus on investigating the patterns in the financial statement fraud cases that took place in the Turkish financial services sector between 2012 and 2020. Moreover, the researcher suggests that institutions that are awarded legal allegations versus institutions that are awarded only monetary sanctions are significantly different from each other; thus stating that the fraudulent companies are managed somewhat differently. 


\section{Data and Methodology}

In this study, the audit findings of CMB were investigated and any findings on financial statement fraud were included in the analysis. For this purpose, the period after the major legal developments was covered in the framework of this article. Audit findings of CMB were e announced periodically in CMB's weekly bulletin and all weekly bulletins between 2012 and 2020 were reviewed to detect all financial statement fraud cases related to the financial services sector. The investigation period started in 2012 because before this year CMB did not announce audit findings clearly. It is not possible to trace audit findings concerning financial statement fraud before this year. Therefore, any audit findings before 2012 were not included in the analysis. There were 301 financial statement fraud cases between 2012 and 2020 concerning all types of institutions CMB was responsible for auditing. However, 34 real-life financial statement fraud cases belong to financial services companies in the period mentioned above.

CMB can sanction financial institutions or make an allegation to the prosecution office depending on the nature of the audit findings. During the period between 2012 and 2020, CMB sanctioned a total of TRY 1,133,904 for noncompliance with CMB regulations and CMB made allegations on 19 cases.

There are 27 audit findings concerning intermediary institutions, 3 audit findings concerning banks and 4 audit findings for portfolio management companies. Therefore, intermediary institutions are at a higher risk when compared to other financial institutions. Moreover, financial statement fraud differs according to the type of institution. For intermediary institutions, the most common type of financial statement fraud is asset misappropriation. There were 16 cases concerning asset misappropriation in the period between 2012 and 2020 .

Since CMB audit findings are highly relevant in the trustworthiness of the financial institutions, the author suggests that institutions subjected to legal allegations have to be significantly different from the institutions that are only sanctioned. Therefore, the following hypothesis is developed for this paper.

$\mathrm{H}_{1}$ : Institutions with sanctions are significantly different from institutions with legal allegations.

There are two variables in the research; these are called "Sanction" and "Legal Allegation". The universe consists of financial institutions involved in fraud for these variables. "Sanction" is a variable that shows the amount of sanction a financial institution has received from CMB between 2012 and 2020. Legal Allegation is a dummy variable that shows whether the financial institution was involved in legal allegations pursued by CMB. Data used in the analysis did not follow a normal distribution as can be seen from Table 3 below. Therefore, nonparametric correlation analysis was used to analyse the data. 
Table 3

Tests of Normality

\begin{tabular}{|c|c|c|c|c|c|c|}
\hline \multirow[t]{2}{*}{ s } & \multicolumn{3}{|c|}{ Kolmogorov-Smirnova } & \multicolumn{3}{|c|}{ Shapiro-Wilk } \\
\hline & Statistic & df & .Sig & Statistic & df & .Sig \\
\hline Sanction &, 301 & 34 &, 000 &, 577 & 34 &, 000 \\
\hline Legal allegation &, 368 & 34 &, 000 & 633 & 34 &, 000 \\
\hline
\end{tabular}

\section{Banks}

The definition of banks includes deposit banks, participation banks, development and investment banks established in Turkey or abroad that have branches in Turkey. Banks are regulated by the Banking Regulation and Supervision Agency (BRSA) concerning compliance with banking law and related regulations in their money market transactions. Banks can also engage in capital market activities, therefore they are also regulated and audited by CMB.

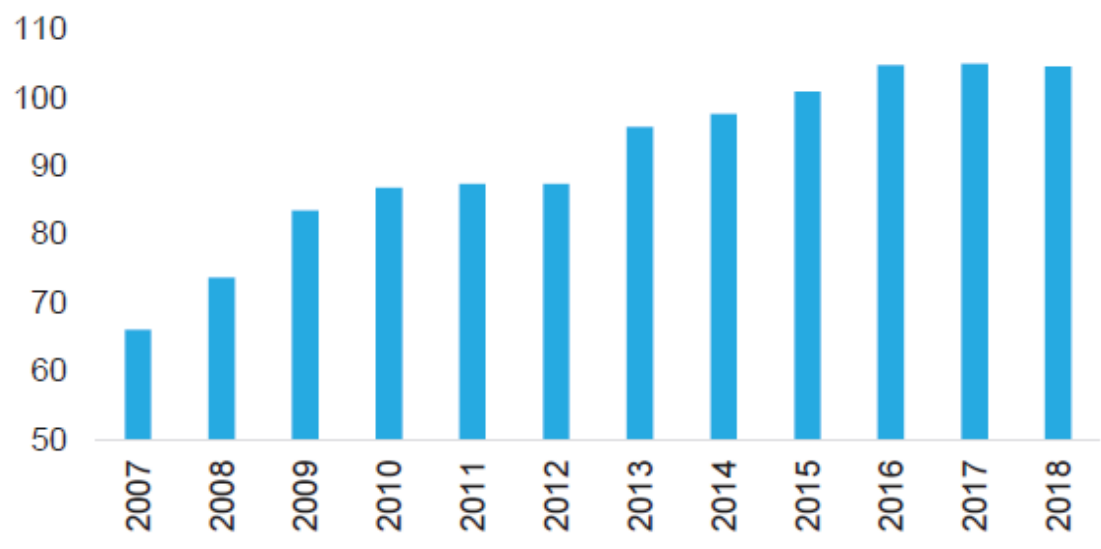

Figure 3. The ratio of assets to GDP (\%) Source: (BRSA, 2019)

There are 43 active banks with 205,157 employees in Turkey as of April 2020. Figure 3 above shows the ratio of bank assets to GDP in percentage. According to the figure, there has been positive growth in the Turkish banking sector since the credit crisis of 2008. Banks have a trading volume of TRY 153 billion in the equity market, TRY 354 billion in fixed income markets, TRY 6,336 billion in the repo-reverse repo market, TRY 62 billion in the futures market, and TRY 3 billion in the options market (Turkish Capital Markets Association, 2020a).

Table 4

Financial Statement Fraud Cases in Turkish Intermediary Institutions

\begin{tabular}{cccc}
\hline Fraud Type & $\begin{array}{c}\text { Related } \\
\text { Regulation }\end{array}$ & Number of Cases & $\begin{array}{c}\text { Legal } \\
\text { Action }\end{array}$ \\
\hline $\begin{array}{c}\text { Reduction of the bank's } \\
\text { assets }\end{array}$ & $\begin{array}{c}\text { CML No 6362 } \\
\text { Articles 21 and 110 }\end{array}$ & 3 & Legal allegation \\
\hline
\end{tabular}


Table 4 above shows the only typology of fraudulent activity detected in the banking sector in the period between 2012 and 2020. This fraud type is the reduction of the bank's assets via various transactions. There were three cases detected for the same bank in 2018 and CMB made legal allegations in $r$ all three cases. In the first case, the bank's assets were reduced by TRY 5,884,689 (excluding interest) due to paying compensation for employees leaving the bank that did not match similar applications with peers, market practices, or the prudence and integrity of commercial life. In the second case, the bank's assets were reduced by TRY $6,865,294$ (excluding interest) by purchasing shares of a real estate investment trust with a price that exceeded similar transactions. The final case concerns the reduction of the bank's assets by a total of TRY 150,777.77 (excluding interest), due to overpayment of the members of the board of directors by more than the amount of attendance at the General Assembly meetings (without a reasonable or legal reason). Note , this bank went bankrupt in 2016, therefore all audit findings belong to two years after the bankruptcy.

\section{Intermediary Institutions}

Intermediary institutions are the go-between between the investors and the issuers that are willing to trade securities in a market organized or over-the-counter. Capital Market Law No 6263 (CML) defines intermediary activities as order transmission to other intermediaries or markets and proprietary trading. Intermediary institutions are also allowed to perform investment advisory, IPO intermediation, custody services and other activities that CMB (2012) decides according to CML Article 37. The CMB is authorized to approve the establishment of intermediary institutions, and such institutions are required by regulation to fulfil several necessities to receive the approval of the CMB. An intermediary institution has to have the amount of capital required by the $\mathrm{CMB}$, founders and personnel have to have clean legal records, have collaterals for the stock market, clearing and investor compensation should be paid and an organizational structure that incorporates constant monitoring with internal audit, risk management and internal control should be established according to Article 9 of Communiqué on Principles of Establishment and Activities of Investment Firms, Serial III39.1 (CMB, 2013a).

In Turkey, there are 62 active intermediary institutions as of April 2020. Seventeen of these institutions are owned by banks. Figure 4 below shows the aggregated total assets of intermediary institutions. In 2010, the aggregated total assets of intermediary institutions were close to TRY 8 billion, however, with each passing year, total assets kept growing. This growth trend is partially imposed by regulation, since the parliament passed the new CML in 2012, according to which, intermediary institution capital requirements were raised for different activities. However, the capital amount has kept on rising since 2012, therefore it is possible to conclude that there is an organic growth trend in the sector. 


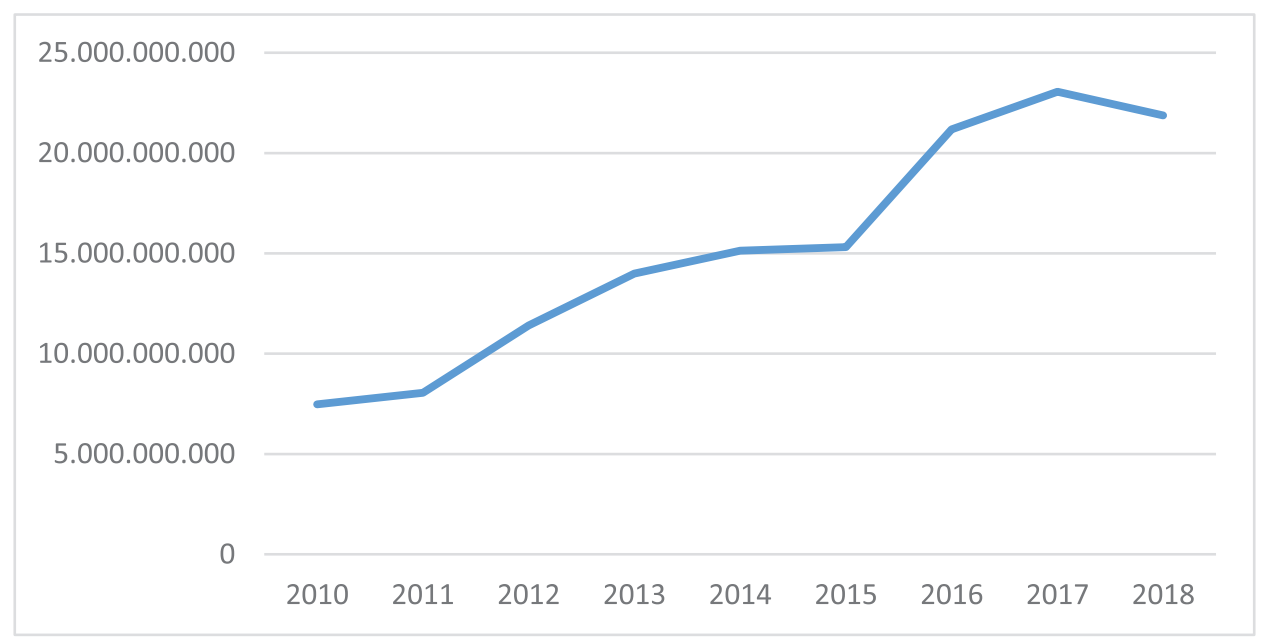

Figure 4. Total Assets of Intermediary Institutions Between 2010 and 2018 (TRY)

Source: Adopted by the researcher from TSPB, 2020.

The following numbers paint a picture of what the Turkish intermediation sector looks like today. The number of investors in Turkish intermediary institutions is equal to 4,654 with 180 corporations and 4.474 individual investors. Assets under the management of intermediary institutions equal TRY 3,595 million with TRY 1,744 million belonging to corporations and TRY 1,852 million belonging to individual investors. Brokerage firms provide credits equal to TRY 2,309 million. Moreover, there are 4,839 people employed in the sector (Turkish Capital Markets Association, 2020a).

Figure 5 presented below shows the distribution of the yearly number of fraud cases in intermediary institutions between 2012 and 2019. The years 2012 and 2016 have the highest numbers and 2017 and 2019 have the lowest number of cases. The frequency of fraud cases shares little information. What matters the most is that each year, there are some cases concerning financial statement fraud in intermediary institutions, whether small or big in scale. This is a major indicator of the problematic nature of brokerage firms, there is most definitely a fraud scheme going on even in the most trusted brands of the sector. Increased regulation has little to no effect on this phenomenon because the CMB has sanctioned many brokerage firms for not installing fully functioning internal audit and internal control systems. If these internal systems do not exist or even if they do exist, they do not function. Under such circumstances, it would not be possible to detect any fraud cases. Moreover, a lacking control environment that feeds the fraud-based culture of these institutions would be created. 


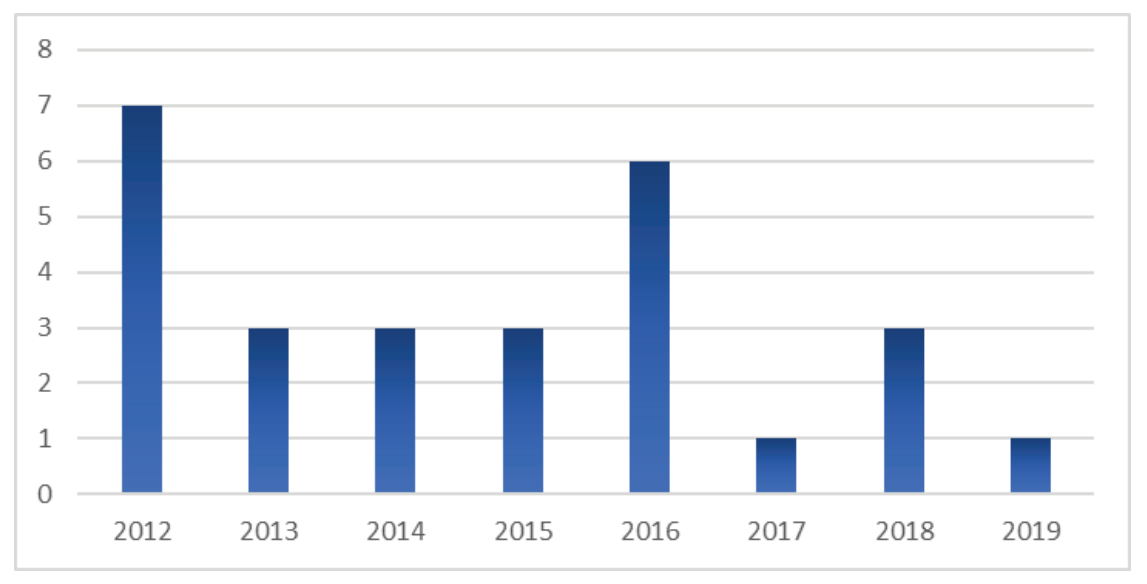

Figure 5. Number of Fraud Cases in Brokerage Firms Between 2012 and 2019 Source: Adopted by the researcher from CMB Weekly Bulletins between 2012 and 2019

Table 5 presented below summarizes the financial statement fraud cases of intermediary institutions between 2012 and 2020. During this period, the CMB either sanctioned intermediary institutions for noncompliance with regulations or made legal allegations. There are 16 cases of legal allegations and the total amount of sanctions is equal to TRY 1,035,995 for 12 cases. There are 27 cases in total (one case includes both an allegation and a sanction). Table 2 further categorizes these fraud cases according to typology.

There are 10 types of financial statement fraud present in the CMB audit findings. Type 1 concerns incorrect adjustment records in the financial statements. This action violates Turkish Accounting Standard 8 Accounting Policies, Changes in Accounting Estimates and Errors. The CMB fined the intermediary institution TRY 18,492. There is only one intermediary institution that is involved in this type of violation.

Type 2 is the violation of the legislation of the intermediary institutions using customer cash collectively and not informing the customers and distributing the income proportionately to related customer accounts. There is only one intermediary institution that committed this violation according to CMB audit findings and CMB fined the institution TRY 38,308.

Type 3 is asset misappropriation by the intermediary institution. In this case, the top management of the brokerage firm used the cash balance in various customer accounts in favour of the institution without the knowledge of customers. This type of fraud is quite dangerous because it damages the mutual trust that the financial services sector is built on. Customers may find that their savings are misused and their trust in the financial system may waver. There is only one intermediary institution that committed this fraud. The intermediary institution is fined TRY 60,000, which is a minor sanction compared to the crime committed.

Type 4 concerns the violation of accounting principles concerning short sale transactions. According to "Communiqué on Principles Regarding Record Keeping and Documentation in 
Intermediary Activities" Serial V No 6 Article 28 (CMB, 1992), collaterals for short sales are recorded as a debit to the cash account and credit to margin account if the collateral is cash. In the case of collaterals, they are deposited as securities then related accounts have to be used. The intermediary institution was fined TRY 135,926 for this violation.

Table 5

Financial Statement Fraud Cases in Turkish Intermediary Institutions

\begin{tabular}{|c|c|c|c|c|}
\hline $\begin{array}{l}\text { Fraud } \\
\text { Type }\end{array}$ & Fraudulent Act & $\begin{array}{c}\text { Related } \\
\text { Regulation }\end{array}$ & $\begin{array}{c}\text { Number of } \\
\text { Cases }\end{array}$ & $\begin{array}{c}\text { Legal } \\
\text { Action }\end{array}$ \\
\hline 1 & $\begin{array}{l}\text { Incorrect adjustment } \\
\text { records in the financial } \\
\text { statements }\end{array}$ & Turkish Accounting Standard 8 & 1 & $\begin{array}{l}\text { Fine equal to } \\
\text { TRY } 18,492\end{array}$ \\
\hline 2 & $\begin{array}{l}\text { Not providing sufficient } \\
\text { information to the cus- } \\
\text { tomer concerning his/her } \\
\text { cash situation }\end{array}$ & $\begin{array}{l}\text { Communiqué III-39.1 Article } 24 \\
\text { Communiqué III-37.1 Article } 66\end{array}$ & 1 & $\begin{array}{c}\text { Fine equal to } \\
\text { TRY } 38,308\end{array}$ \\
\hline 3 & $\begin{array}{c}\text { Asset misappropriation } \\
\text { by the institution (Client } \\
\text { assets) }\end{array}$ & $\begin{array}{l}\text { Communiqué Serial V No } 46 \text { Article } \\
\qquad 58 / 1(\mathrm{~g})\end{array}$ & 1 & $\begin{array}{l}\text { Fine equal to } \\
\text { TRY } 60,000\end{array}$ \\
\hline 4 & $\begin{array}{l}\text { Not applying the provi- } \\
\text { sions on accounting for } \\
\text { short sale transactions }\end{array}$ & $\begin{array}{l}\text { Communiqué Serial V No } 6 \text { Article } \\
28\end{array}$ & 1 & $\begin{array}{l}\text { Fine equal to } \\
\text { TRY } 135,926\end{array}$ \\
\hline 5 & $\begin{array}{l}\text { Capital adequacy miscal- } \\
\text { culation }\end{array}$ & $\begin{array}{c}\text { Communiqué Serial V, No } 34 \text { Arti- } \\
\text { cle } 4\end{array}$ & 1 & $\begin{array}{l}\text { Fine equal to } \\
\text { TRY } 325,617\end{array}$ \\
\hline 6 & $\begin{array}{l}\text { Irregularity in official } \\
\text { documents }\end{array}$ & $\begin{array}{c}\text { CML No } 6362 \\
\text { Article } 112 / 2 \\
\text { Communiqué III-45.1 Article } 7 / 1 \text {-a, } \\
14 \text { and } 14 / 1 \text { Communiqué Serial V } \\
\text { No 6, Article } 5\end{array}$ & 4 & $\begin{array}{c}\text { Fine equal to } \\
\text { TRY } 169,333 \text { and legal } \\
\text { allegation }\end{array}$ \\
\hline 7 & $\begin{array}{l}\text { Intermediary Institution } \\
\text { personnel acting in con- } \\
\text { tradiction with the inves- } \\
\text { tor's rights and interests }\end{array}$ & $\begin{array}{l}\text { Communiqué Serial V, No } 46 \text { Article } \\
\qquad 58 / 1(1)\end{array}$ & 4 & $\begin{array}{c}\text { Fine equal to } \\
\text { TRY 288,319 and legal } \\
\text { allegation }\end{array}$ \\
\hline 8 & $\begin{array}{c}\text { Asset misappropriation } \\
\text { by personnel (Client } \\
\text { assets) }\end{array}$ & $\begin{array}{l}\text { CML No } 2499 \\
\text { Article 47/I-(A)-5 } \\
\text { CML No } 6362 \\
\text { Article } 110 / 1-\mathrm{a}\end{array}$ & 11 & Legal allegation \\
\hline 9 & $\begin{array}{l}\text { Fictitious accounting } \\
\text { transactions and misrep- } \\
\text { resentation in financial } \\
\text { statements }\end{array}$ & $\begin{array}{c}\text { CML No } 2499 \\
\text { Article 47/1-(B) } \\
\text { CML No } 6362 \\
\text { Article } 112 / 2 \text {-a and c }\end{array}$ & 2 & Legal allegation \\
\hline 10 & $\begin{array}{l}\text { Providing CMB with } \\
\text { false information }\end{array}$ & $\begin{array}{c}\text { CML No } 2499 \\
\text { Article 47/1-(B)-1 }\end{array}$ & 1 & Legal allegation \\
\hline
\end{tabular}

Type 5 is about the calculation of the capital adequacy level. Intermediary institutions are required to calculate and report their capital adequacy levels to the CMB periodically. The principles of this calculation are given in Communiqué on Principles Regarding Capital and Capital Adequacy of Brokerage Houses (CMB, 1998). In this case, the intermediary institution failed to show the unsecured receivables of the intermediary institution from the related 
persons as a discount item in the calculation of the capital adequacy base. The CMB fined the institution TRY 325,617 for this violation.

Fraud type 6 detected in the CMB audits is the irregularity in official documents. This violation has some variety, such as non-issuance/incomplete issuance/duplicate issuance of cash receipts, organizing fake portfolio documents to customers, opening false accounts, concealing irregular transactions, imitating the signatures of customers and brokerage firm employees, and using fake company stamps. There are four cases with these violations and in some cases, the CMB sanctioned the institutions, whereas in other cases the CMB made legal allegations. This type of fraud calls for the participation of top management as well as related personnel, therefore it is one of the critical types of fraud and there cannot be any solution from within the company for such cases where the management of the company is not separated from the owners.

Type 7 is the type of fraud where the customer representative misguides the client and performs unnecessary transactions causing the cash deposit (collateral) to slowly decrease in favour of the intermediary institution since every necessary or unnecessary transaction results in commission fee payments for the client. Similar to fraud type 6 , the CMB both sanctioned and made legal allegations depending on the nature of the case in question.

Fraud type 8 concerns asset misappropriation by intermediary institution personnel. In these cases, intermediary institution employees created a loss in the client account by transferring the securities to their account and using it for their own or his/her manager's gain. Type 8 is the most frequent type of fraud, with eleven cases. Unfortunately, in none of these cases, internal audit and internal control functions of the brokerage houses could detect the fraud. All cases were found out by client complaints to the CMB. This is an indication of how unreliable and dysfunctional intermediary institutions' internal audit and internal control departments are. Even though CMB regulation has been updated to improve the strictness of the control environment by imposing restricting rules, it hasn't done much improvement in the tone at the top. Moreover, if the same type of fraud is committed by the management of the intermediary institution, no legal allegations are made. However, if personnel commit the same type of fraud, then they face legal allegations and capital market license termination.

Fraud type 9 is misrepresentation in financial statements and reports in an unrealistic way and creating fictitious accounting records. The CMB audit findings do not elaborate on the details of which accounts have been tampered with, therefore it is not possible to say anything more than legal allegations were made in these two cases.

In the final type of fraud, fraud type 10, the intermediary institution employees hid financial information related to the intermediary institution and gave false information to CMB officials. Again, CMB made legal allegations for this case. 


\section{Portfolio Management Companies}

Portfolio management is defined as managing the pool of assets that are specified by the $\mathrm{CMB}$ under the risk and income preferences of the clients. This definition shows that not all assets can be included in the portfolio and the CMB has to approve the funds before they become available for the public. Portfolio management companies are also regulated by the CMB. Portfolio management companies are allowed to establish funds, manage those funds and perform investment advisory for their clients. A distinctive part of the definition above is that the assets of the fund are separated from the assets of the portfolio management company (CML 6362, Article 53).

In Turkey, there are 50 active portfolio management companies as of April 2020. Eleven of these companies are owned by banks. The total assets under management by the sector equal TRY 284,326,472,430 (TSPB, 2020). Figure 6 below presents the growth of mutual funds in Turkey. According to the figure, in 2013 the total amount of mutual funds was close to TRY 50 billion, whereas in 2019 this number reached TRY 250 billion. There is an increasing trend in mutual funds in Turkey, as investors prefer to channel their savings to mutual funds due to significantly lower taxation opportunities.

According to Wang, et. Al. (2019), mutual fund investments serve for the detection of fraud related to financial statements and decrease the firms' disposition towards fraud. Therefore, investing in mutual funds acts as a restriction for top management. Although investing in mutual funds is becoming popular among investors, this interest can also be attached to the detailed scrutiny of portfolio management companies by the CMB. The CMB has imposed many restrictive clauses that are related to the establishment of portfolio management companies. According to Article 44 of CML, not all individuals can be involved in this process. A person who wants to found a portfolio management company has to have a clean criminal record, should not have any unpaid tax obligations or gone bankrupt in the past. In short, a portfolio management company owner is required to have a clean record and possess the financial stability that is required by the CMB. The starting capital requirement for a portfolio management company is equal to TRY 2 million.

Communiqué on Portfolio Management Companies and Activities of Such Companies, Serial III-55.1 (CMB, 2013b) states that portfolio management companies are required to set up internal audit, internal control and risk management systems to ensure the healthy running of daily operations and that portfolio managers adhere to restrictions and rules imposed by the CMB in regulations (Articles 11, 12 and 13). However, the regulation does not define any potential fraud cases or how internal control is required to take precautions to prevent fraud in portfolio management. 


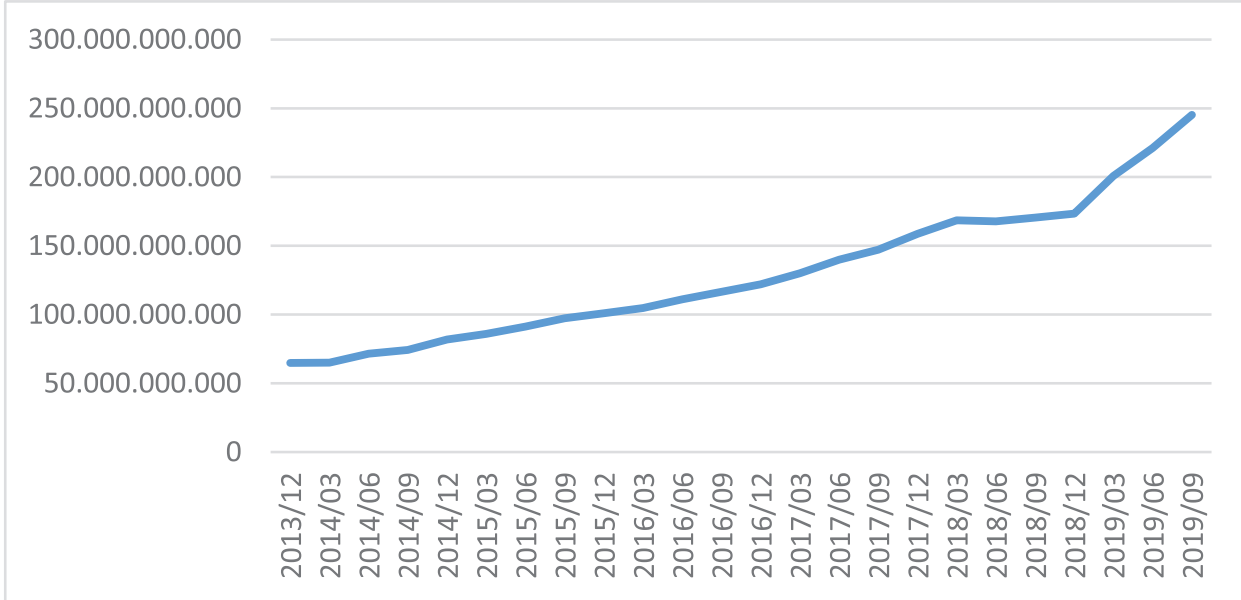

Figure 6. Growth of Mutual Funds in Turkey (TRY)

Source: Adopted by the researcher from TSPB, 2020.

Table 6

Financial Statement Fraud Cases in Turkish Portfolio Management Companies

\begin{tabular}{|c|c|c|c|c|}
\hline $\begin{array}{l}\text { Fraud } \\
\text { Type }\end{array}$ & Fraudulent Act & Related Regulation & $\begin{array}{l}\text { Number } \\
\text { of Cases }\end{array}$ & Legal Action \\
\hline 1 & $\begin{array}{l}\text { Transferring defaulted } \\
\text { bonds among the funds } \\
\text { managed by the company } \\
\text { after the default date; in } \\
\text { favour of one or more of } \\
\text { the portfolios. }\end{array}$ & $\begin{array}{c}\text { Article } 33 \text { Clause } 1 \text { (e) } \\
\text { Of Communiqué } \\
\text { No III-55.1 } \\
\text { (Rule of objectivity in management of more than } \\
\text { one fund) }\end{array}$ & 2 & $\begin{array}{l}\text { Fine equal to } \\
\text { TRY 57,010 } \\
\text { (combined } \\
\text { total) }\end{array}$ \\
\hline 2 & $\begin{array}{l}\text { Committing fraud by act- } \\
\text { ing in favour of personal } \\
\text { gain in case of conflict of } \\
\text { interest }\end{array}$ & $\begin{array}{c}\text { Article } 33 \text { Clause } 1(\mathrm{~d}) \\
\text { Of Communiqué } \\
\text { No III- } 55.1 \\
\text { (Rule of acting as a prudent agent) }\end{array}$ & 1 & $\begin{array}{c}\text { Fine equal to } \\
\text { TRY } 22,407\end{array}$ \\
\hline 3 & $\begin{array}{c}\text { Non-compliance with } \\
\text { the Communiqué in the } \\
\text { capital adequacy base } \\
\text { calculations }\end{array}$ & $\begin{array}{c}\text { Article } 4 \text { Clause } 1 \text { (b) of Communiqué } \\
\text { Serial V No } 34 \\
\text { (Capital Requirements) }\end{array}$ & 1 & $\begin{array}{c}\text { Fine equal to } \\
\text { TRY } 18,492\end{array}$ \\
\hline
\end{tabular}

Table 6 above shows the sanctions imposed by the CMB on portfolio management companies between 2012 and 2020. There are four sanctions in total. Even though there are four sanctions given to different portfolio management companies, the typology of fraudulent acts is limited to three. These can be summarized as non-compliance with the rule of objectivity in managing multiple funds, conflict of interest and noncompliance with capital adequacy calculation rules.

According to Article 33 of "Communiqué on Portfolio Management Companies and Activities of Such Companies" (CMB, 2013b), portfolio management companies are prohibited from performing transactions that favour one portfolio over another, therefore portfolio managers have to be objective and cannot take sides. Type 1 is about portfolio management com- 
panies invested in junk bonds that defaulted and moved these bonds to a certain fund after the default date and thus resulting in a loss for one fund and preventing loss in the other fund.

In fraud type 2, a portfolio management company acted in its favour instead of looking out for the interest of the clients' assets, therefore, taking advantage of its position as an agent in a conflict of interest situation. According to Article 10 of "Communiqué on Portfolio Management Companies and Activities of Such Companies" (CMB, 2013b), portfolio management companies have to take precautions to prevent any conflict of interest that is bound to come up during daily activities and install a conflict of interest policy that will serve the integrity of the market. The conflict of interest in portfolio management is based on the principal-agent relationship. Portfolio management companies can make any investment-related decision concerning client accounts and if the company is managing multiple funds including proprietary trading, then there is a concern of guarding client interest.

Furthermore, in fraud type 3, the portfolio management company in question tempered with the capital adequacy calculations to create an impression of a healthy financial situation. According to Communiqué Serial III-55.1 (CMB, 2013b), portfolio management companies are required to report their capital adequacy status to the CMB every two weeks and the calculation of capital adequacy status is determined in Communiqué on Principles Regarding Capital and Capital Adequacy of Brokerage Houses - Serial V, No 34 (CMB, 1998). The portfolio management company in question violated Article 4 of the aforementioned Communiqué, which describes the funds owned by the company as receivables from third parties except for client collaterals. It is highly probable that the portfolio management company wrongfully included client collaterals in the capital adequacy calculations.

\section{Findings}

According to nonparametric Spearman correlation results, the correlation coefficient is equal to -0.909 which indicates a very strong negative correlation between received sanctions and legal allegations. The correlation analysis is significant at the 0.01 level. Analysis results are presented in Table 6 below. As a result, the null hypothesis is rejected.

Table 7

Correlation Analysis Results

\begin{tabular}{|c|c|c|c|}
\hline & & \multirow[b]{2}{*}{ Sanction } & \multirow[b]{2}{*}{ Legal allegation } \\
\hline & & & \\
\hline \multirow{3}{*}{ Spearman's } & Correlation Coefficient & 1,000 &,$- 909^{* *}$ \\
\hline & Sig. (2-tailed) & . &, 000 \\
\hline & $\mathrm{N}$ & 34 & 34 \\
\hline rho & Correlation Coefficient &,$- 909^{* *}$ & 1,000 \\
\hline \multirow[t]{2}{*}{ Legal allegation } & Sig. (2-tailed) &, 000 & . \\
\hline & $\mathrm{N}$ & 34 & 34 \\
\hline
\end{tabular}




\section{Solutions and Recommendations}

The cases described concerning the banks, present fraudulent activities directed by the board of directors. Such cases cannot be prevented by establishing an internal audit department or robust internal controls since auditors are employees of the bank and their jobs depend on the board members' opinions. However, these cases could have been detected by independent auditors before the bankruptcy.

According to the results of the analysis, it is possible to say that intermediary institutions are more prone to fraudulent activities. This situation is more related to the paradigm of the management of these institutions. Top management is more concerned with making a profit and employees are looking for personal gain rather than serving clients. Moreover, the lack of properly functioning internal audit and internal control departments make it possible for fraudsters to reach their goals.

Even though there are a few fraudulent cases, it is possible to say that portfolio management companies have a small amount of noncompliance detected over the years, which makes these companies more trustworthy when compared to intermediary institutions. The lack of legal allegations shows that portfolio management companies are relatively more secure when compared to intermediary institutions.

Analysis results show that financial institutions that are awarded sanctions and subjected to legal allegations are significantly different from each other. If a company is sanctioned, it is highly unlikely that it will be subject to legal allegations. This finding can be considered as an important indicator of the trustworthiness of the financial institution. Furthermore, fraud cases detected between 2012 and 2020 by the CMB show that top management and in some cases board of directors are involved in fraud. In these cases, the CMB should be taking strict action and making legal allegations against the fraudsters with an equal stance. Moreover, the CMB should be requesting periodical reports from internal audit, internal control and risk management departments similar to capital adequacy reports. This will act in favour of increased scrutiny and force top management of financial institutions to take the control environment more seriously. To achieve stricter controls the CMB's resources should be increased to cover related expenses.

\section{FUTURE RESEARCH DIRECTIONS}

There is a tendency to increase regulation in financial markets. This is an important result of the 2008 economic crisis. The crisis was a turning point for capital market regulation as it increased fraudulent activities. Moreover, fraud cases are on the rise all over the world and financial market institutions are quite vulnerable to fraud in the current economic environment. 
This article's purpose is to draw attention to financial statement fraud in financial institutions which can be overlooked.

The most restricting part of this research is the fact that the CMB's weekly bulletins contain a large amount of information: with more time it would be possible to conduct more detailed research on a larger framework. Further research could be performed to investigate older weekly bulletins and compare the period after 2012 with the period before 2012 to point out how the fraud trends have evolved. This type of research would aid the regulators to enhance their precautions.

\section{Conclusion}

In today's world, the robustness of an economy is more dependable than ever and the public tendency is to expect the financial institutions to be sound and healthy because these institutions make up a significant part of the economic system. The economic crisis of 2008 was critical because it involved financial institutions where public savings are evaluated. Any disruption in these institutions has grave results for the real economy, consequently for the employees who work in the real sector. In short, the overall health of the economy depends on the healthiness of its financial services sector.

Fraud is a major disruptive phenomenon concerning the economy whether detected in the real sector or the finance sector. Any fraudulent activity seen in a firm causes the firm to lose a large number of assets, lose credibility and even go bankrupt. In literature, it is possible to see real sector financial statement fraud cases covered in detail, however, the financial services sector is somewhat neglected. Since the financial services sector is so important for economies, financial statement fraud in the Turkish financial services sector was covered in this article. Banks, intermediary institutions and portfolio management companies are included in the financial services sector framework.

The capital market in Turkey is regulated by the CMB and they periodically announce audit findings concerning all regulations of the capital market. This is also valid for financial reporting and accounting related regulations. Therefore, in this article, the audit findings of the CMB concerning financial statement fraud between 2012 and 2020 were investigated for banks, brokerage houses and portfolio management companies. The total number of financial statement fraud cases detected by the $\mathrm{CMB}$ in the finance sector during this period is equal to 34 . The majority of the cases belong to intermediary institutions. The most common fraud type seen in intermediary institutions is the misappropriation of client assets by employees. Generally, employees transfer client assets (cash and securities) to their accounts and use these assets for personal expenses or use client assets to their pleasure in capital market activities without the knowledge of the clients. There is only one bank involved in financial statement fraud, which was subject to the reduction of assets through misuse, such as overpayments 
to related parties. As a result, the bank in question went bankrupt, however, this was not discovered beforehand by independent auditors. For portfolio management companies, the most frequent type of fraud is favouring one portfolio over another by the company. This is achieved by transferring defaulted assets to a certain portfolio and causing a decrease in the portfolio value.

In all cases of fraud in financial services companies, the common ground is that the tone at the top in these institutions is faulty. Generally, top management and even the board of directors is involved in fraud. This situation calls for increased scrutiny in the financial services sector. Even though the CMB went through a major change in 2012 - 2013 and all related regulations were updated, there is still room for improvement concerning the audit staff resources. The increased fraud cases can only be prevented by equally increased audits. To secure the future of capital markets, the CMB needs to be supported furthermore with upgraded resources.

Peer-review: Externally peer-reviewed.

Conflict of Interest: The author has no conflict of interest to declare.

Grant Support: The author declared that this study has received no financial support.

\section{References}

Acero, I., \& Alcalde, N. (2020). Directors' compensation: What really matters? Journal of Business Economics and Management, 21(1), 180-199.

ACFE. (2003). Fraudbasics. https://www.acfe.com/article.aspx?id=4294967876.

ACFE. (2018). Report to the nations. https://s3-us-west-2.amazonaws.com/acfepublic/2018-report-to-thenations.pdf

ACFE. (2020). Common financial statements fraud. https://brisbaneacfe.org/library/third-party-fraud/common-financial-statement-frauds/

Banking Law No. 5411. (2005). Retrieved from https://www.mevzuat.gov.tr/mevzuat?MevzuatNo=5411\& MevzuatTur=1\&MevzuatTertip $=5$

Carmichael, D.R. (2020). Financial statement fraud by external parties. CPA Journal, March 2020, 28-34.

Chimonaki C., Papadakis S., Vergos K., \& Shahgholian A. (2019). Identification of financial statement fraud in Greece by using computational intelligence techniques. In Mehandjiev N., Saadouni B. (Eds.) Enterprise applications, markets and services in the finance industry (pp. 39-51), Springer.

CMB. (1992). Communiqué on principles regarding record keeping and documentation in intermediary activities serial v no 6. Retrieved from http://www.cmb.gov.tr/SiteApps/Teblig/Index/o.

CMB. (1998). Communiqué on principles regarding capital and capital adequacy of brokerage houses. Retrieved from http://www.cmb.gov.tr/SiteApps/Teblig/Index/o.

CMB. (2012). Capital market law no 6362. Retrieved from http://www.cmb.gov.tr/Sayfa/Index/1/1

CMB. (2013a). Communiqué on principles of establishment and activities of investment firms, serial iii-39.1. Retrieved from http://www.cmb.gov.tr/SiteApps/Teblig/Index/n . 
CMB. (2013b). Communiqué on portfolio management companies and activities of such companies, serial iii-55.1. Retrieved from http://www.cmb.gov.tr/SiteApps/Teblig/Index/n .

Demir, M., \& Arslan, Ö. (2018). Assessment of the importance ratings of the tools used in the determination of financial reporting frauds by independent auditors' perspectives. Journal of Social Sciences, Issue 30, 1099-1142.

Eser, S. (2007). Kuresellesme cercevesinde Turkiye'de bankacilik ve BDDK. (Unpublished master dissertation). Dicle University Graduate School of Social Sciences, Diyarbakir.

Gee, J., \& Button, M. (2019). The financial cost of fraud 2019. http://www.crowe.ie/wp-content/uploads/2019/08/The-Financial-Cost-of-Fraud-2019.pdf

PWC. (2018). Pulling fraud out of the shadows: Global economic crime and fraud survey 2018. Retrieved from https://www.pwc.com/gx/en/forensics/global-economic-crime-and-fraud-survey-2018.pdf

Reurink, A. (2016). Financial fraud: A literature review, MPIFG discussion paper, no. 16/5. https://www. econstor.eu/bitstream/10419/141282/1/859161242.pdf

SDIF. (2020). Tarihce. Retrieved from https://www.tmsf.org.tr/en-us/Tmsf/Info/tarihce.en

Selimoğlu, S., \& Altunel, M. (2019). Master/Phd theses prepared about financial statement fraud and fraud audit: academic literature between 2008 and 2018 in Turkey. Journal of Accounting \& Finance. 2019 Special Issue, 127-140.

Tax Procedure Law No. 213. (1961). Retrieved from https://www.mevzuat.gov.tr/MevzuatMetin/1.4.213. pdf.

Terzi, S., \& Kıymetli Şen, İ. (2015). Detecting frauds in forensic accounting using neural network model. International Journal of Economic \& Administrative Studies, 7 (14), 477-490.

Terzi, S., \& Kiymetli Şen, İ. (2012). Determination of fraudulent financial statements using data mining: A research in manufacturing sector. Journal of Accounting \& Taxation Studies (JATS), 5(2), 25-40.

Turkish Capital Markets Association. (2020a). Data. Retrieved from https://www.tspb.org.tr/wp-content/uploads/2020/06/Turkish_Capital_Markets-202006-TR.pdf

Turkish Capital Markets Association (2020b). Members Factsheet. Retrieved from https://www.tspb.org.tr/ wp-content/uploads/2020/04/UYE_Factsheet_2020_03.xlsx

Turkish Criminal Code No. 5237. (2004). Retrieved from https://www.mevzuat.gov.tr/MevzuatMetin/1.5.5237.pdf

Wang, Y., Ashton, J.K., \& Jaafar, A. (2019). Does mutual fund investment influence accounting fraud? Emerging Markets Review, 38, 142-258.

World Economic Forum. (2019). Why enterprise risk management is the future for banks. Retrieved from https://www.weforum.org/agenda/2019/11/why-enterprise-risk-management-is-the-future-for-banks/

Zengin, S. (2018). Finansal tablo hileleri ve bobi frs kapsaminda ornek uygulamalar. Ankara, Turkey: Seckin. 
